University of Wollongong

Research Online

Faculty of Social Sciences - Papers (Archive) Faculty of Arts, Social Sciences \& Humanities

2020

Urban greening and mobility justice in Dhaka's informal settlements

Razia Sultana

University of Wollongong, rs362@uowmail.edu.au

Thomas Birtchnell

University of Wollongong, tbirtchn@uow.edu.au

Nicholas J. Gill

University of Wollongong, ngill@uow.edu.au

Follow this and additional works at: https://ro.uow.edu.au/sspapers

Part of the Education Commons, and the Social and Behavioral Sciences Commons

Research Online is the open access institutional repository for the University of Wollongong. For further information contact the UOW Library: research-pubs@uow.edu.au 


\title{
Urban greening and mobility justice in Dhaka's informal settlements
}

\author{
Abstract \\ Urban greening in Dhaka, Bangladesh is fraught with injustice for slum dwellers. Access to the commons \\ for the enactment of gardening, farming and foraging by the urban poor, many recent internal migrants \\ from rural areas, is contested by wealthier citizens, developers and political elites. Through qualitative \\ research with households within the informal settlement of Korail in Dhaka's urban core, and a range of \\ stakeholders in governmental and non-governmental organizations, this study critiques competing policy \\ visions that involve urban greening and urban green infrastructure. Repurposing the conceptual lense of \\ 'mobility justice' to analyse environmental and ecological issues in the global South, the findings highlight \\ the importance of mobility concerns to just futures for urban planning. \\ Disciplines \\ Education | Social and Behavioral Sciences \\ Publication Details \\ Sultana, R., Birtchnell, T. \& Gill, N. (2020). Urban greening and mobility justice in Dhaka's informal \\ settlements. Mobilities, 15 (2), 273-289.
}




\section{Urban Greening and Mobility Justice in Dhaka's Informal Settlements}

Razia Sultana, Thomas Birtchnell \& Nicholas Gill (2020) Urban greening and mobility justice in Dhaka's informal settlements, Mobilities, 15:2, 273-289, DOI: $\underline{\text { 10.1080/17450101.2020.1713567 }}$

\section{ABSTRACT}

Urban greening in Dhaka, Bangladesh is fraught with injustice for slum dwellers. Access to the commons for the enactment of gardening, farming and foraging by the urban poor, many recent internal migrants from rural areas, is contested by wealthier citizens, developers and political elites. Through qualitative research with households within the informal settlement of Korail in Dhaka's urban core, and a range of stakeholders in governmental and nongovernmental organizations, this study critiques competing policy visions that involve urban greening and urban green infrastructure. Repurposing the conceptual lense of 'mobility justice' to analyse environmental and ecological issues in the global South, the findings highlight the importance of mobility concerns to just futures for urban planning.

KEYWORDS: Bangladesh, slums, urban green infrastructure, policy, poverty, sustainable development

\section{Introduction}

Bangladesh's major urban centre, Dhaka, is a confluence for internal migrants seeking a better life through mobility. Yet upon arrival the majority face instability as they establish dwellings within informal settlements and enact urban greening based on their own interests and foreknowledge. Urban (Freudendal-Pedersen and Kesselring 2016), migration (Hammond 2011), and border (Vollmer 2017; Drakakis-Smith 2007) politics are a regular fixture in this journal. After Sheller (2018), we consider in this paper the role of 'mobility justice' in urban greening policies that affect informal settlements. Internal migrants to Dhaka make use of the urban commons and assert their right to the city through farming, gardening and community foraging; however, they face competing policy visions that attempt to move them away from their homes, gardens and 'green infrastructure' within informal settlements. Informing the mobilities of Dhaka's poorer citizens are policies that shift across boundaries: cities, nationstates and-pertinent to this paper-hemispheres, such as from global North to South (Jacobs 2012; McCann 2013). These policies reimagine the role of urban greening as a mechanism for economic growth, wellbeing, and cosmopolitan creativity in a way that simultaneously excludes the urban poor (Temenos and McCann 2013).

Of value to critical scholarly attention to mobility justice in Dhaka is failure, demobilization, barriers to action, and the unevenness of social justice when policy fashions move between the global North and South (Cook 2018; Sheller 2016). Reflecting on this focus, Lovell (2019) raises concerns over policy failures and the consequences of governance knowledge flows on people's lives as they cross radically different socio-economic areas, an entry point for critical mobilities scholars with an interest in social justice (McLean and Borén 2015).

One such cosmopolitan policy fashion in the twenty-first century is urban greening with major pushes happening in both international and municipal contexts in the global North, driven in part by the United Nations' sustainable development goals, and citizenry concerns about climate change. Amongst intragovernmental and non-state organizations urban greening is 
attracting policy attention (OECD 2016) for having multiple socio-economic dividends for communities and neighbourhoods as well as ensuring ecosystem services at the city scale (Jim 2013). The term urban greening encompasses various forms including parkland, community gardening, tree plantations, landscaping and so on (Ghose and Pettygrove 2014). In recent times, roof-top gardening, green walls, green alleys, rain gardens, and urban creeks are additions that are being implemented to meet cities' sustainability goals (United Nations 2016). Urban greening offers environmental benefits in various areas such as subsistence (Mudu and Marini 2018) air quality improvement (Bottalico et al. 2017), rainwater run-off and flood management (Thorne et al. 2018), countering the urban heat island effect (Ambrey et al. 2017), supporting biodiversity (Threlfall et al. 2017) and more broadly mitigating the impacts of climate change (Ramyar and Zarghami 2017).

Policy mobilities on urban greening occur between global North and South as regions are included in the action plans of major intragovernmental organizations. For instance, The World Bank's 2018 'Country Environmental Analysis' report details the important role Bangladesh's government has to play in becoming 'clean and green' to match standards in the global North (Kemper and Fan 2018). Bangladesh's government is responsive to these mobilities of policies on urban greening. On World Environment Day in June 2019, Prime Minister Sheikh Hasina urged city dwellers to plant at least three saplings (a fruit tree, a timber tree and a medicinal tree) each to boost the urban canopy as a part of the National Tree Plantation Campaign 2019 at a special event in Dhaka. During the event the Prime Minister gave out National Environmental Awards to organizations and stakeholders in academia, industry and NonGovernmental Organizations (NGOs). Although a commendable gesture, what about those residents of informal settlements who are not permitted to plant trees? Or who cannot afford to plant them?

Attention to mobility justice arises due to manifold issues in Dhaka's informal settlements. Street trees are cut down for firewood; community gardens are co-opted for further informal dwellings; and water sources are polluted and clogged by invasive weeds, rubbish and sewerage. This paper, therefore, is an attempt to fill the gap between the aspirations of policy makers to action urban greening in accord with overseas governance interests and the lived reality of Dhaka's citizens. For this study, we analyse mobility justice on urban greening from the viewpoint of social rights and equitable access to the urban commons.

This paper examines how predominant social, economic, infrastructural and environmental factors hinder policy action on urban greening in one particular informal settlement in central Dhaka, Bangladesh: Korail. Two prominent streams of urban greening policymaking, which Bangladesh's government are attempting to deploy in tune with global efforts, are critiqued. Firstly, is the resettlement of Korail's residents out of the urban core in order to develop urban greening for rate- and tax-paying citizens. Second, there is the redevelopment of informal settlements within the urban core into dense mixed-use conurbations blending residential and corporate ownership to fund and manage urban greening. While perhaps plausible in the global North these urban greening policies are woefully inadequate for the global South.

In response, two alternatives are proposed that consider the issues residents of informal settlements face that are unique to them. First, policy recognition of their existing urban greening activities. Second, resourcing residents to enact urban greening drawing on their own practices, competence and skills. In offering these two policy counterpoints, this paper provides space for debates on encouraging critical attention to the 'forgotten' places of informal settlements, seeking to counter pervasive malaise amongst the rest of the citizenry and 
disinclination for real action by politicians solely responsive to global policies rather than local issues.

The subjects of this paper are residents of informal settlements, many of whom have migrated from rural areas to Dhaka at some point in their lives. There is a pervasive sense that residents of informal settlements are outsiders of the city with no formal property assets and no municipally acknowledged right to the city. Despite their liminality in cosmopolitan society they are inextricable to wealthier citizens' daily lives. Low-income workers living within informal settlements provide services to the city as maids, servants, cleaners, rickshaw pullers, street cleaners and gardeners. Ironically, many of them live without municipal coverage (waste disposal, sewers, power, or emergency services) in their own homes and this leads to destitution, giving the impression to Dhaka's other residents that informal settlements' residents do not care for their homes and surroundings.

\subsection{Research Question}

From our field research, we surmise that urban greening is active at the grassroots in Korail, yet it is misaligned with policies moving into Bangladesh from the global North, which emphasize policy support for urban greening motivated by wellbeing and aesthetic concerns out of reach of the urban poor. Our research involving residents of informal settlements and policy stakeholders offers the following research question: how do urban greening policies from the global North to South translate into action within informal settlements? In addressing this question, we are attuned to current debates amongst various experts including academics, urban planners, architects, NGOs and International Non-Governmental Organizations (INGOs) on this issue. We argue that challenges with translation of policy explain the impotency of urban greening in Korail and consider this idea in the next section. After a brief introduction to the current state of policymaking, section two highlights challenges in Korail for urban greening. Section three presents the methods utilized in this study. Section four provides overall discussion in relation to the findings of the research. Section five draws conclusions and recommendations to break the stalemate for ecologically more sustainable informal settlements in Dhaka, Bangladesh. 


\section{Urban Greening Policies}

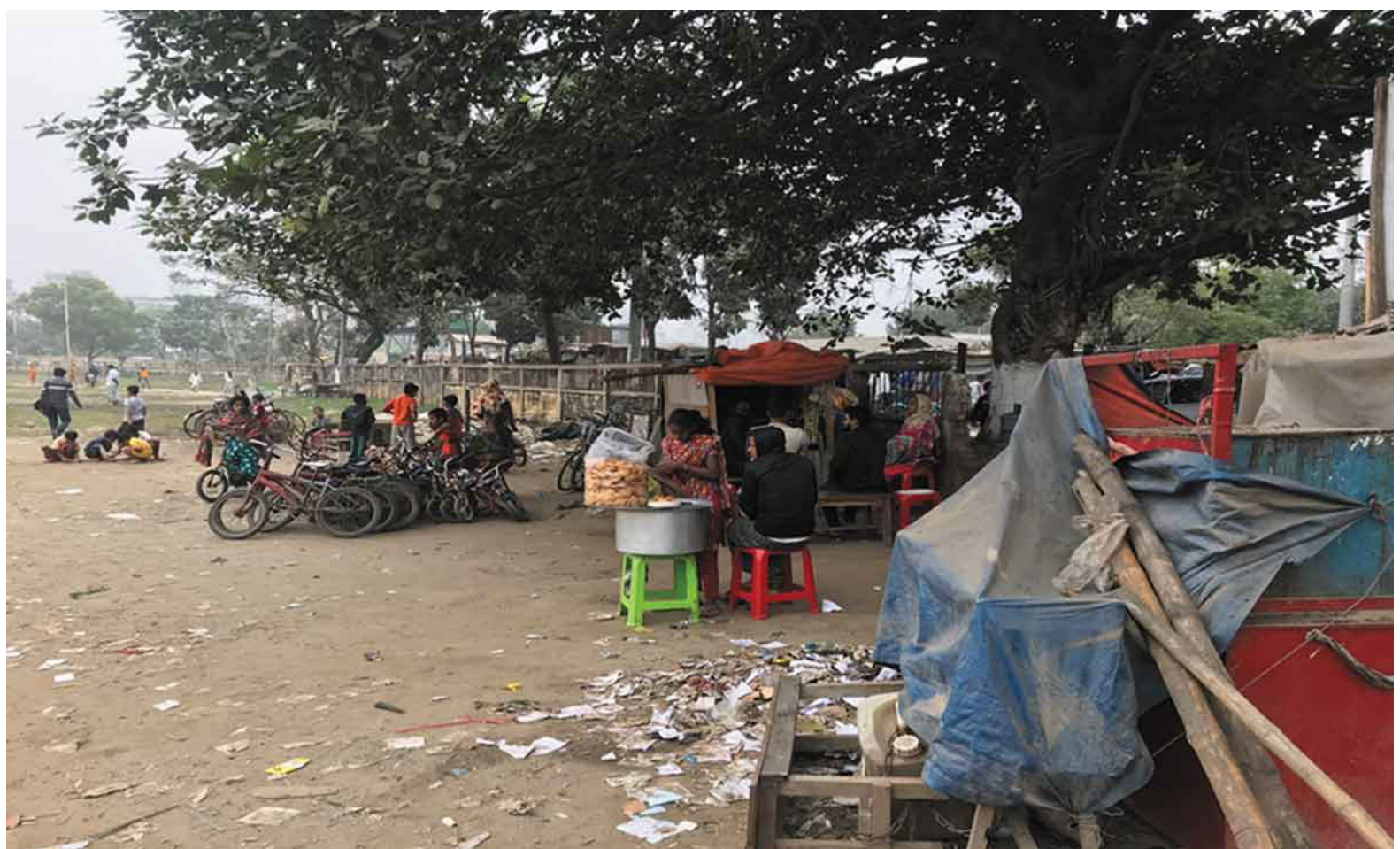

Figure 1. Shade trees offer a space for socializing, commerce and bicycle parking in Korail (source: authors).

In Bangladesh greening policies fall into the purview of strategies to mitigate flooding, erosion and agricultural catastrophes in rural areas (Ingham, Rabiul Islam, and Hicks 2019). In the urban context action is more complex. Despite growing policy awareness of the need for urban greening in line with the mobility of other policy trends from the global North (see Swapan and Khan 2018), Dhaka's informal settlements, described in Bangladesh' governance circles as 'bastees' (slums), have the fewest green spaces in the entire city and as such are out of bounds in such considerations (Byomkesh, Nakagoshi, and Dewan 2012). In world cities, urban greening has been an important approach to making the urban environment more liveable, resilient and inclusive (Tappert, Kloti, and Drilling 2018; Sandhu et al. 2016). Regrettably, urban greening has become a challenge in those informal settlements where city dwellers live without municipal support and struggle to receive services and amenities.

Since informal settlements receive paltry municipal planning, urban politics are a powerful force in shaping the policy landscape on urban greening, which tend towards excluding and exploiting residents. Urban greenery that does exist in informal settlements certainly provides services to residents (Figure 1.); however, it faces multiple threats and receives little support or planning coverage. Urban greening reveals other multifaceted problems in informal settlements such as a lack of outright ownership, limited affordable housing, pressures for resettlement, and the threat of eviction. All of these factors impact upon socially just interventions in urban greening.

There is a notable disparity between policies on urban greening globally and locally in Bangladesh (Mell 2017). In the cities of the global North urban greening is understood in two ways: as eco-aesthetic 'beautification' or as cost-effective, or ecologically prudent, risk management (Matthews, Lo, and Byrne 2015). The idea is yet to be systematically implemented in Dhaka in either sense. 
Another reality of cities in the global South is the mobilities of migrants to urban informal settlements. Those who extensively work on urban greening in Dhaka view livelihoods, wellbeing and social capital as key areas for policy attention (Gopal and Nagendra 2014). Within informal settlements, 'community gardens', or 'urban agriculture', are an important vehicle for supporting these features (Adegun 2017; Hosking and Palomino-Schalscha 2016). Unfortunately, in many cities in South Asia (such as in Bangladesh), community gardening or urban agriculture is contested due to land scarcity, slum households' limited financial capacity, and other related issues (Birtchnell, Gill, and Sultana 2018). Moreover, environmental degradation limits remedial action (Figure 2).

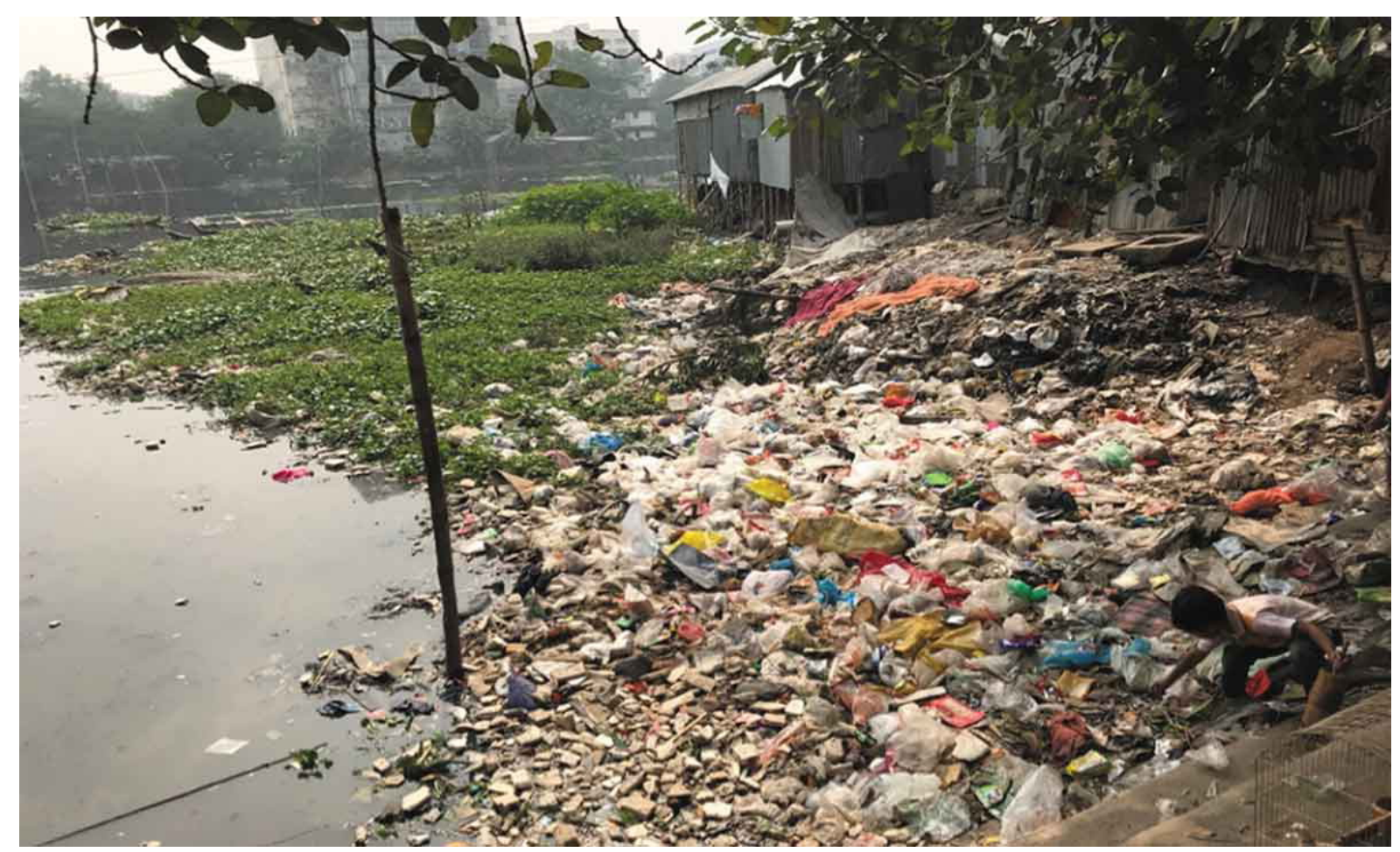

Figure 2. Pollution in Gulshan Lake, Korail hampers weed management (source: authors).

For the purpose of our study, we amalgamate the urban greening concept with issues more widely understood in studies of mobility justice in the urban commons (Diaz et al. 2018). The urban commons are conceived as commonly owned spaces (such as parks, local streets, housing, and public spaces) and services for which city dwellers have shared responsibilities, on the one hand, and collective rights to access those resources, on the other (Huron 2015; Kornberger and Borch 2015). The urban commons idea attends to politics relating to governance, biodiversity, poverty, and land management (Ginn and Ascensao 2018). Alongside access to resources, the urban commons is a space where citizens socialize, trade, and conduct leisure activities (Kip 2015; Ostrom 1990). In the global North, the urban commons is for the most part well managed by the stable rules of municipal administration or private configurations and the services are accessible to all citizens irrespective of social class (Ghertner 2012). Conversely, the urban commons in the global South is less official, with many undocumented and unordered facets, in which services are regulated by local leaders and corrupt elements (e.g., in Bangladesh mastaans or gangsters).

\section{Methods}

The primary method in this project was qualitative drawing on semi-structured interviews. The project was granted approval by the institutional ethics committee prior to 
commencement. The interviews were conducted in Bengali and English, depending upon each participant's proficiency and predilection, as one of the authors is fluent in both languages. The analysis was conducted first on the original recordings and then on the transcripts, which were translated by one of the authors for the other research team members. Throughout the rest of the paper the word 'bastee' is translated as 'slum' and this term is used interchangeably for 'informal settlement'.

Two sets of questions were deployed for the different cohorts of participants. The interview questions for Korail's residents focused on their own efforts at urban greening within their households and community and were accompanied by observational research. Residents were also asked about their perceptions of municipal and governmental support for urban greening and the different visions imagined by the state. Stakeholders were asked about their awareness of Korail's existing urban greening, the relevant current and future policies and plans, and the impact of urban greening visions on long-term residents and recent arrivals to the city.

\subsection{Interviews with Residents of Informal Settlements}

Korail is the largest and densest informal settlement in Dhaka holding more than 200,000 residents (Adri and Simon 2018). Korail is an appropriate site for this study considering the size, density, heritage and location of the conurbation and its proximity to a major water body and greener, wealthier suburbs (Figure 3). Korail is subject to widespread unauthorized land and house development leading to endemic inequality in electricity flow (Karim, Hossain Lipu, and Mahmud 2017); water and sanitation; access to roads and drainage (Degert, Parikh, and Kabir 2016); and waste accumulation. The latter is a key issue for urban greening as uncollected rubbish (including household compost and human waste) is dumped in water bodies or burnt in the open, causing exposure of residents to levels of airborne particulate matter 20 times higher than is recommended in Dhaka (Husain 2015).

Currently the status of urban greening in Korail is uncertain due to the problems of land insecurity, land scarcity, presence of crime, and other socio-political hurdles. In order to understand these complex phenomena, we conducted semi-structured interviews with 30 households in Korail for three consecutive months (2016-17) and performed follow up fieldwork in early 2018. Each household included 3-14 people. 25 females and 5 males were interviewed across a range of ages. Households were given questions related to types of urban greening they practice, problems they regularly encounter, and the roles of NGOs and the government in urban greening development. The semi structured interviews also involved participant observation in household spaces and in the wider community. On many occasions, informal information was gathered from gate keepers and influential people in Korail (e.g., members of political parties). 


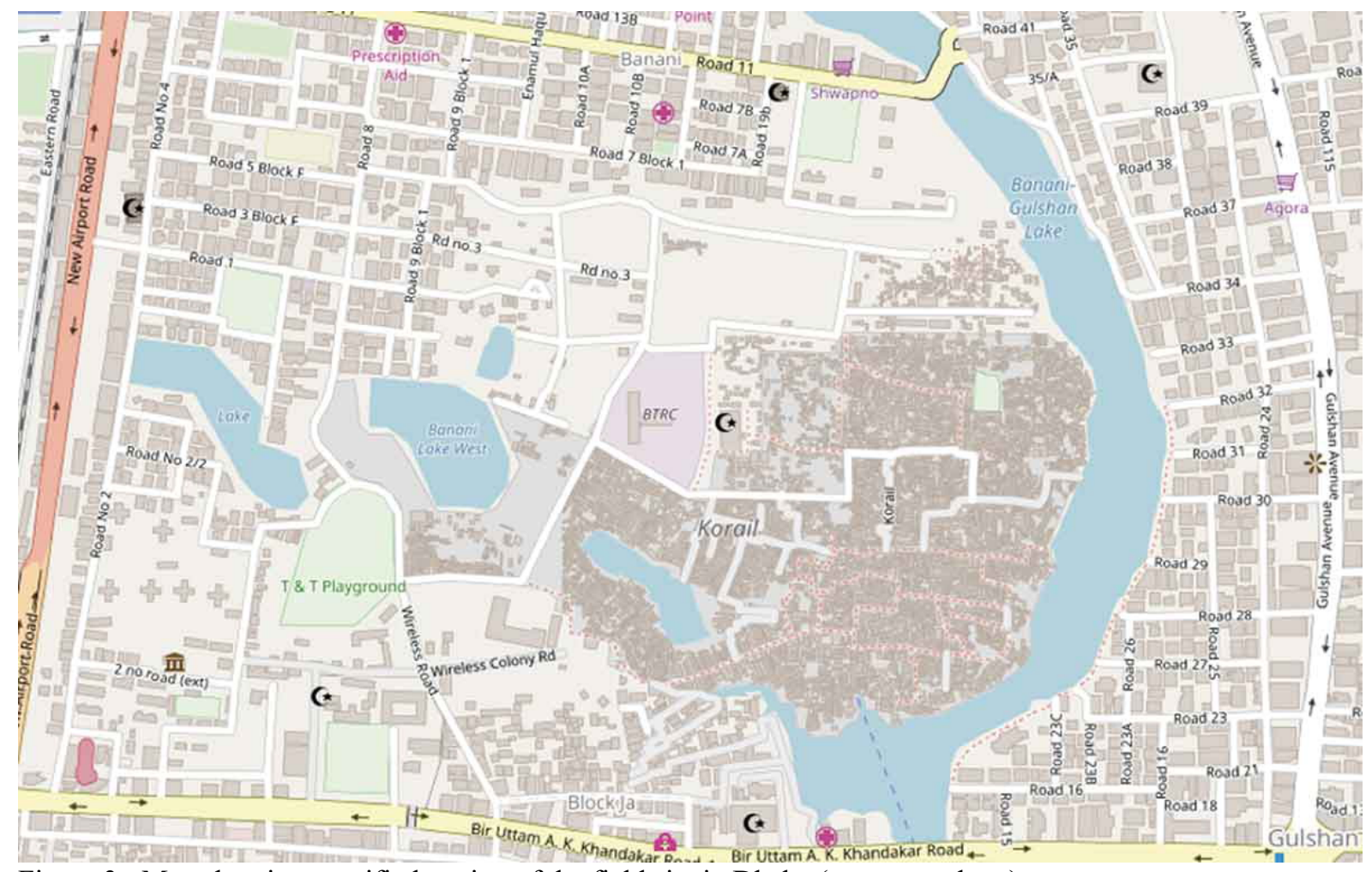

Figure 3: Map showing specific location of the field site in Dhaka (source: authors).

\subsection{Interviews with Stakeholders}

In order to further understand the issues around policies on urban greening in Korail, we also drew from semi-structured interviews with 30 experts informing policy-making in Dhaka. In the study, the term 'experts' refers to those who are targeted as specialists and involved in implementing decision-making processes (Sovacool et al. 2012). We identified six expert groups directly engaged with the different projects in Korail. Interviewees were from (1) NonGovernmental Organizations (NGOs), (2) Community Development Organizations (CDOs), (3) International Non-Governmental Organizations (INGOs), (4) government agencies, (5) academia, and (6) think tanks/architectural firms contracted by government.

We selected NGOs working in Korail and environmental issues, particularly on urban greening. The five major NGOs are Bangladesh Poribesh Andolon (BAPA), Aparajeoyo Bangladesh, Bangladesh Rural Advancement Committee (BRAC), Apon Foundation and Coalition for Urban Poor (CUP). Among the INGOs and donor agency were Concern Bangladesh, Action Aid, Practical Action Bangladesh, United Nations Development Programme (UNDP) and Water Aid. We selected academics from Dhaka University (DU), Jahangir Nagar University (JNU), Jagannath University (JU), North South University (NSU) and BRAC University. Most of the academics were from geography, anthropology and urban and regional planning backgrounds. In the case of think tanks, we relied on five relevant organizations working on climate change adaptation and urbanization issues specifically the Centre for Urban Studies (CUS), International Centre for Climate Change and Development (ICCCAD), Power and Participation Research Centre (PPRC), International Centre for Diarrhoeal Disease Research, Bangladesh (ICDDR-B) and Bangladesh Centre for Advanced Studies (BCAS). To include formal policy-makers, we interviewed policy experts from Dhaka City Corporation (DCC, 19 and 20 Wards), Rajdhani Unnoyan Kartipakha (RAJUK), Urban Directorate and National Housing Authority (NHA). Finally, we selected architects and urban planners who have a reputation for working in various urban development projects in Dhaka. 
To identify the relevant experts and householders in this project, we utilised randomized and purposive sampling methods alongside snowballing from participants. We recorded the discussions with the participants in a field diary. All interviews and narratives were audio recorded and the data analysis involved categorizing based on themes and sub-themes. In the next section we unpack this empirical data according to four distinct themes: resettlement, redevelopment, recognition and resourcing.

\section{Policy Visions for Urban Greening}

In this section we highlight four urban greening policy visions that have implications for mobility justice. Planned urban greening fits with policies that meet international sustainability goals and at the same time economic growth (UNDP 2019). Fulfilling both of these expectations is a fraught process across all visions. We use the term resettlement to refer to the movement of residents of informal settlements elsewhere to alternative sites in the urban periphery in order for it to be allocated to other municipal contexts (Korail lies within Dhaka's urban core and in proximity to desirable amenities, such as Gulshan Lake) that would undertake urban greening alongside a shift in land-use towards formal commercial, residential and recreational purposes (Ramakrishnan 2014). A second option for action towards urban greening in Korail is the redevelopment of the land into planned estates to formalize urban green infrastructure and provide incumbent residents with access to semi-privatized greenspace. Recognition is a core issue for urban greening policies given that informal settlements are a blind spot in urban planning. The ability of residents living within informal settlements to create, maintain, and contribute to urban greening is threatened due to a lack of resourcing and municipal support for their own urban greening activities. These four visions are where urban greening policy failures manifest for reasons explored in the following sections.

\subsection{Resettlement Policies}

Supporting the emphasis on resettlement in the future vision of Dhaka urban core, the government's ambitious aim is to set up knowledge quarters named 'Mohakhali Information and Communications Technology (ICT) Village' in place of Korail, in order to foster economic growth, and introduce planned areas for urban greening that benefit Dhaka's rate-paying residents. The consequence for resettlement is thus demolition of informal settlements, threats to livelihoods and ultimately eviction. These ramifications are not prominent in policies on urban greening in the global North.

In Korail, the government owns 90 acres of valuable land. Existing residents, under this policy vision, are compensated through a municipal planned investment in fringe sites (notably Gazipur and other adjacent areas) providing purportedly superior services, amenities and greenspaces once they vacate Korail. Conceivably, one major reason to choose this location by the government is the overwhelming presence of garment industries there, which will create opportunities for displaced residents. Unfortunately, garment employees are only a small fraction of livelihoods and face increasing insecurity due to automation and shifts in global textiles markets (Banks 2016). Keeping in mind the budget constraints and funding problems so far, the Bangladesh Hi-Tech Park Authority (BHTPA) under the ICT Division of the government, proposes six probable options to ensure access to urban greenery for residents through a private-public partnership (PPP) (Infrastructure Investment Facilitation Company 2014). In this resettlement project various forms of urban greenery are implemented such as parkland, playgrounds, rooftop gardens, community agriculture and street beautification. From RAJUK's perspective - a key capital development authority of the government - resettlement of Korail agrees with a visionary masterplan prepared for the year 2035 spanning Dhaka's 
overall development imagining green corridors, public parks and the repurposing of an old airport site (also home to informal residents) (Hasan 2017).

Access to urban greenery will not be straightforward for removed residents, given there are existing educational and corporate facilities in Gazipur that utilize the green space already, and that will likely increase demand in future. Korail's incumbent residents are given some choices in the project planning of their resettlement; however, these are challenging to reconcile with existing communities in the proposed site or access to the urban commons in Korail once resettlement takes place as one interviewee noted:

Slums are mushrooming haphazardly here and there in Dhaka. When we sit in a policy discussion to address this problem with the government, there are assumptions from their side that slum dwellers have no future in Dhaka, since they are overwhelming the city's resources. They are not even counted as citizens and it is a major drawback in policy at the moment. Whereas, I believe, slum dwellers are essential: they clean our houses or work as security guards at offices. When we require labour at a cheaper rate, we target this group. The government has taken the initiative of Ghore Fera Kormoshuchi (Back Home Programme) of the urban poor. But where will they go?

(2018, F, 40s, Programme Manager, NGO)

In the first and second options in the project, cash compensation is offered as a lure for resettlement by different authorities, and here urban greening is low on their agenda for spending these funds given the costs of moving families and replacing livelihoods or the costs of commuting back to central Dhaka for work. The third and fourth options provide a replacement site with housing in Gazipur or in proximity to the development, and here there are locked-in elements for urban greening. The fifth option is for making the low-cost housing on a rental basis, possibly with urban greening elements included, while the final option is resettlement of the entire settlement of Korail in a grand manner that involves fine-resolution planning and formalized urban green infrastructure. In the rest of the discussion, we attend to the evolving debates among the stakeholders surrounding contemporary issues of ghettoization and eviction with regard to off-site resettlement.

Many of the interviewees perceive the resettlement plans as little short of ghettoization (Powell and Lever 2015) that will disrupt social cohesion and ties resulting ultimately in new satellite informal settlements being created. Indeed, in government there is concern in some quarters about the consequences of resettlement by force:

It will not be a wise decision to build a slum or sweeper colony here [in Gazipur]. Slum dwellers are obliged to go to the new location since this piece of land [Korail] is not their personal or fathers' property. For an adjustment, government might offer them compensation or a relocation option ... if government allocates one lakh [hundred thousand] taka [1US\$ $=84.7289$ Bangladeshi taka] each as compensation they can be rehabilitated within forty-eight hours. No military force is required to relocate them.

(2018, M, 40s, Councillor, government)

Think tank experts comment that the resettlement of Korail's residents could be beneficial for wealthier residents in the short term (promising a 'slum-free' urban core), but in the long term would lead to distinct spatial segregation, as seen in India's caste system, where certain classes 
are resigned to dedicated quarters, even streets, of the city (Ghertner 2012). Ghettoization has some appeal to policymakers, yet in practice is difficult to set into motion, given the reluctance of settled residents to take the risk of losing their livelihoods (Ballard 2012, 566). As a think tank analyst makes clear:

I think the ambitious ICT Village Project is a bureaucratic and coercive attempt of the government since it is not even through a clear policy process. If it is executed ... it will be a naked power exercise from the government.

(2018, M, 50s, Head, think tank)

The strongarm approach necessary to resettle Korail's informal residents, notably land clearing and eviction, unhinges the beneficial aspects of urban greening that policies seek to deliver. The CDOs we interviewed in Korail were unanimous that resettling slum dwellers in Gazipur would be a significant disruption to their lives and to those who depend upon their labour: wealthier citizens also benefit from near access to a cheap workforce residing in Korail. Any urban greening that manifested would not be tenably maintained or a beneficial replacement for the loss of incomes and existing informal green infrastructure, such as shack gardens or mixed private/public ad hoc allotments (many very visible alongside Gulshan Lake), given the lack of employment opportunities in proximity to the projected future precinct.

Eviction is a prominent feature of previous efforts to intervene in Dhaka's informal settlements and has caused a great deal of negative media attention for policymakers. 'Eviction' refers to the forceful removal of residents through the demolition of their existing green and grey infrastructure, detainment by security, military or police forces, and even forced transportation elsewhere. One primary concern observed from other instances of slum eviction in Korail is that it causes distress for residents and criticism from onlookers (Figure 4).

In their study, Hussain et al. (2015) note that eviction serves as a show of sudden force and evicted residents are usually neglected once the 'event' is complete. This is also reinforced from the households we interviewed who noted extensive damage to community and household gardens, shade trees and aesthetic greenery. To support eviction, policymakers highlight the exponential increase of the total number of residents in Dhaka's urban core, and argue that they are at the verge of crisis point. Yet, after a government employee, such extreme measures are unpalatable:

... the slum is an evolving process. As long as the state turns to this kind of action, the process will continue. If the government rehabilitates one particular group another group will set up new informal settlements. When the government evicts one slum, concurrently, another slum will be formed as per the necessity of people and society.

(2018, M, 40s, Town Planner, government)

The steady stream to Korail of new arrivals and returnees from eviction render it an impotent measure in the long-term:

The Prime Minister strictly declares that slum dwellers cannot be evicted without proper rehabilitation. Slum dwellers enhance our labour economy. They are part of our world as well. 
Think tanks, on the contrary, tie eviction to slum politics since residents are a prominent source of votes for the members of parliament (MPs) and ministers. Evictions cause bad press and therefore are only able to occur at certain times within the election cycle. In Bangladesh, electoral clientelism is prevalent similar to many other developing countries where the poor are unduly influenced in voting, for instance with the offer of money, goods, or other consumable items for support (de Wit and Berner 2009). In this regard, one expert notes:

If 10 people are displaced from the slum, the vote bank will be reduced for the local MPs. This strategy can be labelled as 'sustainable poverty' in which poverty is retained due to ensuring a vote bank.

(2018, M, 40s, Policy Coordinator, think tank)

Academics further argue that the government currently adopts a contradictory political stance towards urban greening policies that involve eviction of informal settlements since in a verdict in 1999 the Supreme Court signed a stay order of non-eviction without adequate rehabilitation. Eviction plans now contradict Article 15 of the Bangladesh Constitution articulating the obligations of government to provide basic provisions such as food, clothing, shelter, education, and medical care (Shiree-DSK 2012). Notwithstanding the existing constitutional guarantees and the injunction from the High Court, informal settlements continue to be threatened by demolition and residents live under constant fear of eviction often, and ironically for this paper, inspired by wealthier residents criticizing slum dwellers impacts upon urban greenery (Arman and Mahmud 2017).

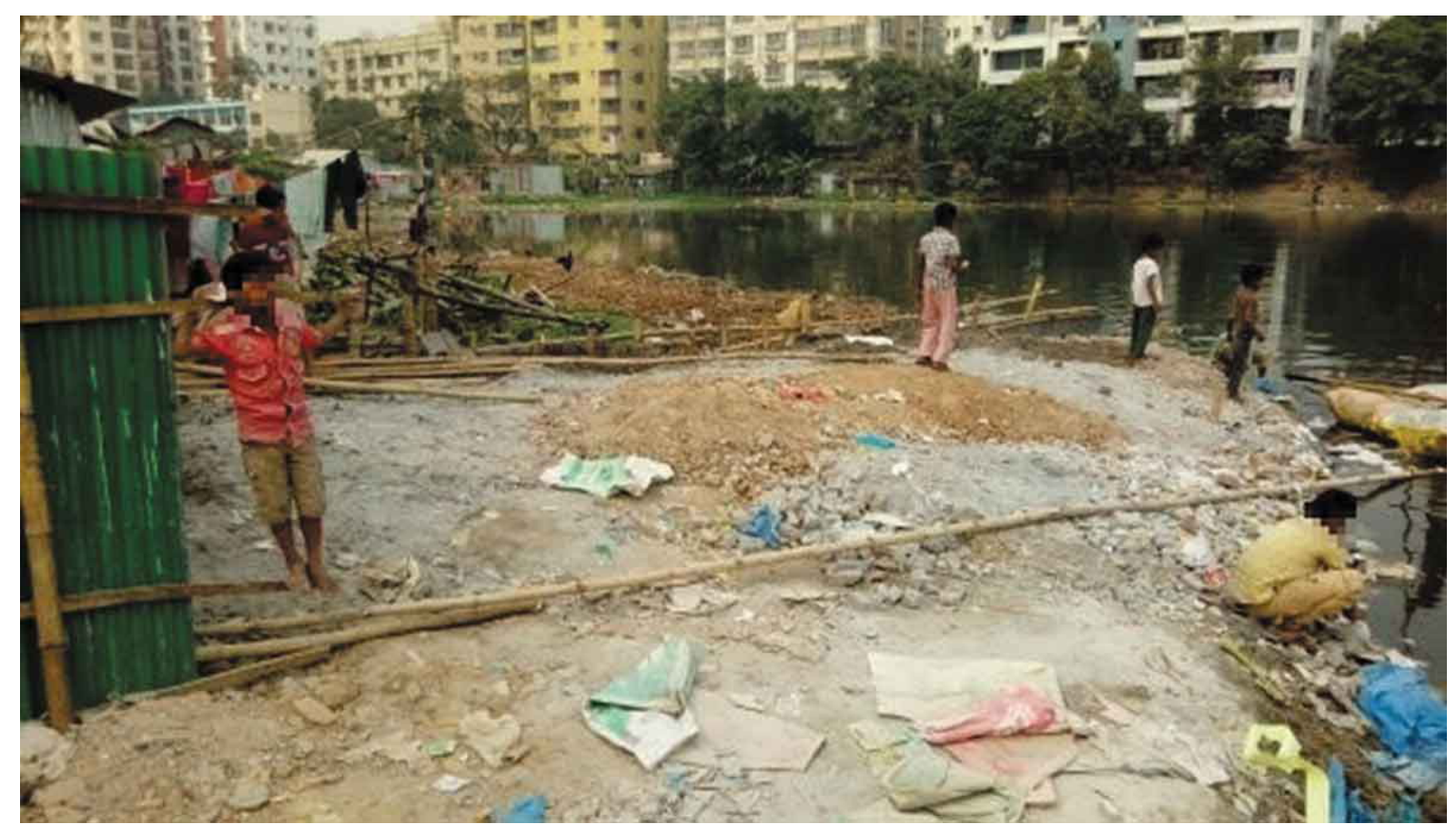

Figure 4: Korail residents after a sudden incident of eviction (source: authors).

\subsection{Redevelopment Policies}

As argued by (Degert, Parikh, and Kabir 2016) so-called slum 'upgrading' reduces urban greening to being an opportunity for profitmaking. The term 'redevelopment' as a policy of 
government and other agencies refer to the en bloc rezoning of existing infrastructure and the replacement of informal settlements with planned ones (Lai, Chau, and Cheung 2018, 241). In the context of Korail, redevelopment is equated to the on-site resettlement of existing slum dwellers, which privileges elites and excludes the vulnerable (Doshi 2013). Since Korail is already an illegal, unplanned and underdeveloped area, the vertical expansion of community housing model faces resistance from incumbents. Experts point out that redevelopment can produce various problems ranging from psychological to economic costs for residents who are unlikely to participate in or benefit from planned urban greening given the amount of space available and the types of projects in the pipeline.

RAJUK, Dhaka's municipal body, project that within 5-10 acres of land incumbent slum dwellers could be rehabilitated through high-rise residential buildings thereby creating more space for urban greening. Architects have hailed this project as an ideal model aligned with global policies on urban greening that segregates greenspace into regulated partitions directly within and around the built environment. Among the planners we spoke to, one school of thought shares the government's preference for high-rise buildings, while another strand of architects suggest dense 'cluster' housing is more conducive for urban greening.

Under a dense mutual housing model, small units are offered to incumbents to achieve two probable dividends: the easeful on-site resettlement of existing households; and, the creation of community space for public greenspace alongside private balcony, in-house, and rooftop gardening. Policymakers are attuned to global urban greening policies from China and Korea with the core idea that existing residents will trade total land space for new and improved internal space.

The second idea centres around the probable option of cluster housing in which each building contains 5-6 floors following a distribution process. With this venture, community space will be allocated for urban greening. The proposition is that both the government and residents will invest financially in urban greening.

The government and urban planners are optimistic about these ideal types of urban planned projects that are in concert with global urban greening policies, but simultaneously doubt residents' level of cooperation due to their financial and legal situations. Our findings here agree with Cavalheiro and Abiko (2015) that redevelopment projects rarely privilege incumbent residents, for instance, in Brazil's favela resettlements where conflict often arises around the funding of state interventions in services or amenities. This point is articulated by one academic in the following way:

A slum household, for instance, does not receive her payment on a daily basis. While receiving the salary after a month, she has to pay the debt, buy food for kids and other necessary items. With the experience of having an inadequate budget, it is difficult for her to join in ostensibly costly redevelopment projects and pay regularly by instalments.

(2018, F, 30s, Assistant Professor, academic)

During our interviews with households it became clear that given the ad hoc nature of informal settlements, incumbent residents do not desire the cosmopolitan lifestyle the government imagines from urban greening policies with origins in world cities such as London, Paris and New York. For instance, living in a high-rise building involves many vulnerabilities in the 
global South such as poor-quality building standards (leading to disrepair and even collapse) and routine utility and power failures.

There is also irony here in this vision because gentrification can lead to intensified urban greening that excludes the urban poor. In redevelopment urban greening is aesthetically motivated and in the case of Dhaka neither beneficial for nor serviceable in terms of providing food, shelter, or other ecosystem services. Significant for policymakers is that when such proposals are made for redevelopment private interests also make counter-claims, often for higher-value plots that are then segregated from the urban poor.

Gentrification (see Stabrowski 2014), wherein redevelopment makes an urban area more appealing to wealthier citizens, acts as an exclusionary force for residents of informal settlements. In the context of the global South, Lemanski $(2014,2946)$ has equated the term as 'downward raiding' which primarily focuses on two connotations: displacement and exclusion. From the vantage point of this research, gentrification is grounded upon neoliberal processes that raise resistance amongst Korail's incumbents. Amongst our interviewee experts think tanks in particular noted that housing redevelopment is state-led gentrification under another guise since it tends to entail the process of exclusion of incumbent slum households.

Referring to a demonstration by residents in 2011 against gentrification and redevelopment of Korail, many of the academics we interviewed asserted that this sort of redevelopment initiative is the ultimate reflection of a top-down interventionist policy and a hallmark of neoliberal hegemony. In the guise of participation and empowerment, redevelopment projects tend to solely reflect the interests of elites, politicians and government officials. Tellingly, in the previous Vasantek Rehabilitation Project (VRP) in Dhaka most of the flats designated for residents of informal settlements were ultimately allocated to wealthy citizens (e.g., local elites). Urban greening here is destabilized by corruption and gentrification.

\subsection{Recognition Policies}

Recognition is a major hurdle to urban greening policies in Korail. Three parties are claimants to the same land in Korail: Bangladesh Telecommunications Company Limited (BTCL), the Public Works Department (PWD) and a consortium of private owners. The decoupling of government rights and private ownership in Korail poses significant challenges in the implementation of greening policies. Two aspects frame the vision: the trust that governments invest in residents to have the capability to enact urban greening and the rights they have to private and public land.

There is limited trust in incumbent residents' potential to be stewards of urban greening. Other rate-paying citizens' expectations, generally informed by desires for beautification rather than ecological or risk management concerns, position residents of informal settlements as anathema to urban greening. The academics we interviewed argue that poor quality informal housing results in various extreme weather events such as flooding, one of the major hazardous problems in Bangladesh's cities, and one that can be remedied by urban greening that tackles erosion, subsistence, easement, drainage and so on. From the contemporary planning perspective, architects identify a lack of systematic drainage and improper waste management by the municipal corporation as key reasons for excessive waterlogging in and around Korail. INGOs and CBOs concur with academics and blame the Dhaka City Corporation (DCC) for unsystematic dumping of waste that contaminates Dhaka's urban water courses and ultimately major lakes in the urban core, such as Gulshan Lake. 
However, government agencies tend to recognize slum residents as the major cause for prolonged waterlogging and pollution in Korail. The government points to the DCC's declaration of Gulshan Lake as an Ecologically Critical Area in 2001, indicative of policy action on urban greening in line with national standards. Yet, due to a lack of recognition of residents and their right to municipal services there is a dearth of regulatory force either for conservation or stewardship since those living near to water bodies depend on them for both sewerage services and for accessible drinking water. Moreover, with no formal systems of waste collection, pollution emerges as a consequence of residents' informality.

A key concept here is accumulation by dispossession. Within Bangladesh's government is a pervasive neoliberal ideology that marginalizes the poor from securing property rights, but preserves the interests of certain groups, notably politicians-cum-landowners (Banks, Roy, and Hulme 2011). Both experts from think tanks and academia address the point that lack of ownership pre-empts residents from practicing urban greening and gives rise to an alternative power structure in slum politics privileging corruption. The householders we interviewed also concur with this point noting the link between insecure tenancy and opportunities for urban greening. Within disputed land local mastaans rather play a crucial role in the housing insecurity, collecting rents and enforcing building and land-use standards. The presence of informal power brokers reinforces further inequality, insecurity and social exclusion (Islam et al. 2006; Begum and Moinuddin 2010). Corruption in Korail has a direct impact upon urban greening (Suykens 2015).

The existing hegemonic and indeed corrupt system at play around recognition of land use and ownership was widely discussed by the architects we interviewed. Residents of informal settlements have to pay landlords rents for 6 square-metre shacks that are costlier than the equivalent apartments of residents in affluent streets opposite Korail in the suburb of Gulshan. A key factor here is that these relationships are beyond the remit of the municipal corporation and the residents are unable to draw on legislative representation or state support mechanisms.

\subsection{Resourcing Policies}

Policymakers acknowledge the issue of resourcing and make forays to intervene in their urban greening efforts through the provision of knowledge, materials and funds for enabling urban greening. The first key hurdle is the debilitating corruption that is endemic in Dhaka's informal settlements. Here there are slum politics and also issues with cronyism and corruption between private and public interests that stultify action on urban greening.

In this section we identify overt and covert corruption obviating the redistribution of resources for urban greening in Korail. In particular, local leaders or mastaans operate as representatives of government officials and broker with the state to derive all manner of benefits, including property rights. Quite often these actors use physical intimidation as an instrument for achieving their interests (such as dispute settlements), which is not accomplished in a legal procedure, but followed through local variations that lack transparency for participants. This fact was constantly reinforced in the interviews with the households.

From the government's perspective, corruption goes hand in hand with the informality of the slum and the unwillingness of the residents to abide by municipal and legal codes and rules. According to the stakeholders we interviewed, policymakers tend to depict informal settlements as places where incivility thrives and where resources are unsecured and difficult to attribute to single outcomes once introduced, such as urban greening. 
Beyond organized corruption, the purported lack of civil norms within informal settlements poses a conundrum for policymakers who aim to provide targeted resources, in waste management for instance (Millington and Lawhon 2018). Raising the point of sanitation and waste disposal in Korail, the government highlights a number of initiatives (community latrines or waste bins) in collaboration with partner organizations (NGOs or CBOs), which assume certain norms are widespread. Here the onus is placed on residents to adopt recognizably civil modes of living:

All people are not perfect who live in the city. If people are not accustomed to urban culture and urbanism, it is hard for the government to make the city liveable.

(2018, M, 30s, Project Coordinator, government)

In this regard, architects remark that when people are beset by poverty civic sense is jettisoned since it is a question of their survival over abiding by civil norms that could make the urban environment greener or more sustainable. The architects we interviewed reflect that it is not slum dwellers' civic sense that inhibits the effective resourcing of urban greening; rather, urban greening is not practised due to the disconnection between civic responsibility and the urban commons. On the whole slum residents do not feel capable of practicing urban greening regardless of the resources they can access. This statement is also supported in a similar study (Ambrey et al. 2017) that describes how comparatively socially disadvantaged groups are less likely to perceive the dividends of urban greening.

Given other realities (such as high rent), it is evident from the interviews with the households that many of them do not have the resources for urban greening. As also recounted by one academic:

Urban greening is an aesthetic thing rather than a necessity for the slum dwellers. They may have the urge but there are so many priorities in their lives.

\section{(2018, F, 40s, Assistant Professor, academic)}

Instead of focusing on civic sense academics attribute under-resourcing as a result of poverty. Their view is that incomes and urban greening are positively correlated issues.

A final issue is itinerancy, since most residents of Korail are rural migrants. Dissimilar to rural areas, there are sharp divisions within informal settlements in terms of income, assets, ethnicity, religion, gender and between property tenants and owners. Since a majority of the residents are itinerant, resourcing them is complicated. This is evident from the statement of an INGO staffmember: 'If we plan for 35 families today, we find that 10 families are missing the following day' (2017, M, 40s, Programme Head, government). Urban greening in Korail is considered in some quarters of policymaking as absurd due to the residents' current exploitation of the environment and inability to commit to policies. Quite often the government has no choice but to acknowledge the right to extract rent and side with private interests due to the itinerancy of residents, many of whom are seasonal workers returning routinely to rural areas. As another government employee comments:

It is noticeable that a number of slum households have made two-storey buildings in Korail. Here, the question is, have they gained permission from anybody? They know 
very well that they cannot stay here permanently. Their mentality is that as long as we are allowed to stay here by the government we will enjoy occupying the site.

(2018, M, 40s, Councillor, government)

Due to the purported and real transiency of slum dwellers, environmental issues have a low priority in policy circles in comparison to the provision of basic services and infrastructure to Dhaka's other residents.

\section{Discussion and Conclusion}

The goal of this paper has been to argue for greater awareness of mobility justice, particularly in policies that have a consequence for the urban poor in the global South. Policy mobilities on urban greening fail in Dhaka's informal settlements due to endemic issues that result in a widespread ennui amongst government officials and other stakeholders that lead to injustice. Observers of Korail might conclude that there is paltry relevance for urban greening in this informal settlement given the near ecological collapse of the major water body, Gulshan Lake, and the standards of living suffered by the majority of residents. However, in this paper we have sought to foreground issues that intimate change in the hope of providing a pathway beyond the 'Catch-22' dilemma many policymakers and commentators find themselves in when contemplating the ecological and aesthetic state of Dhaka's urban core. The four different viewpoints we have examined in this paper on urban greening in Dhaka are all ultimately irreconcilable with achieving urban greening on par with urban centres in the global North. Yet, each of these policy avenues, if mobility justice issues could be brought to light, would result in a radically different outcome for the informal residents of Korail.

In the first instance we considered plans to move slum dwellers in order to replace their own efforts at urban greening, such as ad hoc community and household gardens or lake-side allotments, with formalized planned green infrastructure while at the same time the provision of green-space to them outside of the urban core in a new mixed commercial and residential development. While seemingly a win-win situation, unfortunately such a policy stance emulating similar developments in the global North on urban greening belies the connections between slum dwellers and the urban core's socio-political realities, particularly in the link between the informal economy and proximate living. Hence, resettlement plans are failing to incite meaningful change. Given this link it is no surprise eviction does not achieve this goal and in fact harms political efforts in practice. Hence, we suggest that eviction cannot be the solution and slum dwellers' voices need to be incorporated before taking such a big project like resettlement.

In the second instance, the plan to redevelop Korail alongside, and in collaboration with, slum dwellers appeared difficult to realize due to issues with cost and gentrification that are heightened far beyond the norms witnessed in the global North. While visions of converting the land around Gulshan Lake into a commercial and residential heartland brimming with opportunities for incumbent residents to raise their living standards and achieve urban greening according to the expectations of Dhaka's wealthier residents, there is a risk that this model would simply intensify inequalities and neglect slum dwellers even more. Therefore, government needs to work extensively to identify vulnerable groups and enact policies accordingly.

In the third instance, issues with mobility justice stemming from the recognition of existing residents arise from a lack of trust in their potential to be stewards and moreover many 
unknowns around who is a resident and who has the right to the urban commons. Recognition of citizens as stewards of urban greening invokes systemic issues of corruption and poverty. The lived realities of residents, and the conditions of their spaces, render them vulnerable to exploitation that nullifies plans to recognize and empower them.

Finally, the transiency of residents works against ideals of a model citizenry willing to cocreate ecological and environmental sustainability through resourcing. Like other city dwellers, equitable provision of physical infrastructure for residents is a prerequisite for creating a sustainable environment in cities.

Despite the dilemmas in all four of these models for urban greening in Korail, our goal in this paper is not to sow further despair, but rather to open up a critical space for alternatives to roadblocks in policies that imagine residents' existing efforts at urban greening as on par with global citizens. By highlighting the shortfalls in existing policies in Bangladesh, we hope for a redoubling of efforts to engage with residents of informal settlements and to grant them a right to urban greening. Since urban greening is deeply political and complex, the disconnects in policies will only be overcome if grassroots actors in CBOs, NGOs, INGOs and the academy are given critical space to comment on governance interventions and interest in policies from the global scene. Moreover, by providing a space for non-state actors we aim to highlight their capacities to contribute at the grassroots to breaking the gridlock on urban greening in Korail. 


\section{Bibliography}

Adegun, Olumuyiwa Bayode. 2017. "Green infrastructure in relation to informal urban settlements." Journal of Architecture and Urbanism 41 (1):22-33. doi: 10.3846/20297955.2017.1296791.

Adri, Neelopal, and David Simon. 2018. "A tale of two groups: focusing on the differential vulnerability of "climate-induced" and "non-climate-induced" migrants in Dhaka City." Climate and Development 10 (4):321-36. doi: 10.1080/17565529.2017.1291402.

Ambrey, C., J. Byrne, T. Matthews, A. Davison, C. Portanger, and A. Lo. 2017. "Cultivating climate justice: Green infrastructure and suburban disadvantage in Australia." Applied Geography 89:52-60. doi: 10.1016/j.apgeog.2017.10.002.

Arman, Tanbir Uddin, and Abu Hayat Mahmud. 2017. "Rehabilitation of slum dwellers: Taking the right approach." Accessed 3 March.

https://www.dhakatribune.com/bangladesh/dhaka/2017/03/03/rehabilitation-slumdwellers-taking-right-approach/.

Ballard, Richard. 2012. "Geographies of development: Without the poor." Progress in Human Geography 36 (5):563-72. doi: 10.1177/0309132511431933.

Banks, N., M. Roy, and D. Hulme. 2011. "Neglecting the urban poor in bangladesh: Research, policy and action in the context of climate change." Environment and Urbanization 23 (2):487-502. doi: 10.1177/0956247811417794.

Banks, Nicola. 2016. "Livelihoods Limitations: The Political Economy of Urban Poverty in Dhaka, Bangladesh." Development and Change 47 (2):266-92. doi: 10.1111/dech.12219.

Begum, Halima, and Golam Moinuddin. 2010. "Spatial Dimension Of Social Exclusion. An Imperial Investigation Into The Relationship Of Housing And Social Exclusion In The Slums Of Dhaka City." Management Research and Practice 2 (3):314-28.

Birtchnell, Thomas, Nicholas Gill, and Razia Sultana. 2018. "Sleeper cells for urban green infrastructure: Harnessing latent competence in greening Dhaka's slums." Urban Forestry \& Urban Greening In Press. doi: 10.1016/j.ufug.2018.05.014.

Bottalico, Francesca, Davide Travaglini, Gherardo Chirici, Vittorio Garfi, Francesca Giannetti, Alessandra De Marco, Silvano Fares, et al. 2017. "A spatially-explicit method to assess the dry deposition of air pollution by urban forests in the city of Florence, Italy." Urban Forestry \& Urban Greening 27:221-34. doi: 10.1016/j.ufug.2017.08.013.

Byomkesh, Talukder, Nobukazu Nakagoshi, and Ashraf M. Dewan. 2012. "Urbanization and green space dynamics in Greater Dhaka, Bangladesh." Landscape and Ecological Engineering 8 (1):45-58. doi: 10.1007/s11355-010-0147-7.

Cavalheiro, Débora de Camargo, and Alex Abiko. 2015. "Evaluating slum (favela) resettlements: The case of the Serra do Mar Project, São Paulo, Brazil." Habitat International 49:340-8. doi: 10.1016/j.habitatint.2015.05.014.

Cook, lan R. 2018. "Suburban policy mobilities: examining North American post-war engagements with Vallingby, Stockholm." Geografiska Annaler Seiries B-Human Geography 100:343-58. doi: 10.1080/04353684.2018.1428495.

de Wit, Joop, and Erhard Berner. 2009. "Progressive Patronage? Municipalities, NGOs, CBOs and the Limits to Slum Dwellers' Empowerment." Development \& Change 40 (5):927-47. doi: 10.1111/j.1467-7660.2009.01589.x.

Degert, Isoline, Priti Parikh, and Rumana Kabir. 2016. "Sustainability assessment of a slum upgrading intervention in Bangladesh." Cities 56:63-73. doi: 10.1016/j.cities.2016.03.002.

Diaz, John M., Susan T. Webb, Laura A. Warner, and Paul Monaghan. 2018. "Barriers to community garden success: Demonstrating framework for expert consensus to inform policy and practice." Urban Forestry \& Urban Greening 31:197-203. doi: 10.1016/j.ufug.2018.02.014.

Doshi, Sapana. 2013. "The Politics of the Evicted: Redevelopment, Subjectivity, and Difference in Mumbai's Slum Frontier." Antipode 45 (4):844-65. doi: 10.1111/j.1467-8330.2012.01023.x. 
Drakakis-Smith, Angela. 2007. "Nomadism a Moving Myth? Policies of Exclusion and the Gypsy/Traveller Response." Mobilities 2 (3):463-87. doi: 10.1080/17450100701597467.

Freudendal-Pedersen, Malene, and Sven Kesselring. 2016. "Mobilities, Futures \& the City: repositioning discourses - changing perspectives - rethinking policies." Mobilities 11 (4):575-86. doi: 10.1080/17450101.2016.1211825.

Ghertner, D. Asher. 2012. "Nuisance Talk and the Propriety of Property: Middle Class Discourses of a Slum-Free Delhi." Antipode 44 (4):1161-87. doi: 10.1111/j.1467-8330.2011.00956.x.

Ghose, Rina, and Margaret Pettygrove. 2014. "Urban Community Gardens as Spaces of Citizenship." Antipode 46 (4):1092-112. doi: doi:10.1111/anti.12077.

Ginn, Franklin, and Eduardo Ascensao. 2018. "Autonomy, Erasure, and Persistence in the Urban Gardening Commons." Antipode 50 (4):929-52. doi: 10.1111/anti.12398.

Gopal, Divya, and Harini Nagendra. 2014. "Vegetation in Bangalore's Slums: Boosting Livelihoods, Well-Being and Social Capital." Sustainability 6 (5):2459.

Hammond, Laura. 2011. "Governmentality in Motion: 25 Years of Ethiopia's Experience of Famine and Migration Policy." Mobilities 6 (3):415-32. doi: 10.1080/17450101.2011.590038.

Hasan, Mahamudul. 2017. "Gazipur Dev Authority in the Offing." New Age, Accessed 14 May. http://www.newagebd.net/article/15521/gazipur-dev-authority-in-the-offing.

Hosking, Emma Noëlle, and Marcela Palomino-Schalscha. 2016. "Of Gardens, Hopes, and Spirits: Unravelling (Extra)Ordinary Community Economic Arrangements as Sites of Transformation in Cape Town, South Africa." Antipode 48 (5):1249-69.

Huron, Amanda. 2015. "Working with Strangers in Saturated Space: Reclaiming and Maintaining the Urban Commons." Antipode 47 (4):963-79. doi: 10.1111/anti.12141.

Husain, Mishal. 2015. "The Dhaka slum being transformed by women." In. Asia: BBC News.

Hussain, Rasel, Amit Kumar Saha, Golam Rabbani, Irin Pervin, Wasifa Tasnim Shamma, and Sazzad Hossain Khan. 2015. "State and the Low Cost Housing for the Poor: Fall of Bashentek Rehabilitation Project (BRP) in Dhaka City--Bangladesh." Journal of Education and Practice 6 (13):1-12.

Infrastructure Investment Facilitation Company. 2019. "Feasibility Study for Development of Mohakhali ICT Village." Bangladesh Hi-Tech Park Authority, Accessed 3 July. https://bhtpa.portal.gov.bd/sites/default/files/files/bhtpa.portal.gov.bd/page/fd2c28e6 99 ab 43d4 8262 ff8d87165be7/Draft\%20Feasibility\%20Study\%20Report-\%20Mohakhali.pdf.

Ingham, Valerie, Mir Rabiul Islam, and John Hicks. 2019. "Adaptive flood mobilities in Bangladesh." Mobilities 14 (2):158-72. doi: 10.1080/17450101.2018.1522882.

Islam, Nazrul, A.Q.M. Mahbub, Nurul Islam Nazem, Peter Lance, and Gustavo Angeles. 2019. "Slums of Urban Bangladesh: Mapping and Census 2005." Centre for Urban Studies, Accessed 3 July. https://www.measureevaluation.org/resources/publications/tr-06-35.

Jacobs, Jane M. 2012. "Urban geographies I: Still thinking cities relationally." Progress in Human Geography 36 (3):412-22. doi: 10.1177/0309132511421715.

$\mathrm{Jim}$, C. Y. 2013. "Sustainable urban greening strategies for compact cities in developing and developed economies." Urban Ecosystems 16 (4):741-61. doi: 10.1007/s11252-012-0268-x.

Karim, T. F., M. S. Hossain Lipu, and Md Mahmud. 2017. "Electricity access improvement using renewable energy and energy efficiency: A case of urban poor area of Dhaka, Bangladesh." International Journal of Renewable Energy Research 7 (3):1296-306.

Kemper, Karin Erika, and Qimiao Fan. 2019. "Clean and Green Bangladesh: A goal that can be achieved." World Bank, Accessed 10 July. https://blogs.worldbank.org/endpovertyinsouthasia/clean-and-green-bangladesh-goal-canbe-achieved.

Kip, Markus. 2015. "Moving Beyond the City: Conceptualising Urban Commons from a Critical Urban Studies Perspective." In Urban Commons: Moving Beyond State and Market, edited by Mary Dellenbaugh, Markus Kip, Majken Bieniok, Agnes Katharina Müller and Martin Schwegmann, 42-59. Berlin: Birkhaüser Press. 
Kornberger, Martin, and Christian Borch. 2015. "Introduction: Urban Commons." In Urban Commons: Rethinking the City, edited by Christian Borch and Martin Kornberger, 1-21. London: Routledge.

Lai, Lawrence W. C., K. W. Chau, and Polycarp Alvin C. W. Cheung. 2018. "Urban renewal and redevelopment: Social justice and property rights with reference to Hong Kong's constitutional capitalism." Cities 74:240-8. doi: 10.1016/j.cities.2017.12.010.

Lemanski, Charlotte. 2014. "Hybrid gentrification in South Africa: Theorising across southern and northern cities." Urban Studies 51 (14):2943-60. doi: 10.1177/0042098013515030.

Lovell, Heather. 2019. "Policy failure mobilities." Progress in Human Geography 43 (1):46-63. doi: 10.1177/0309132517734074.

Matthews, Tony, Alex Y. Lo, and Jason A. Byrne. 2015. "Reconceptualizing green infrastructure for climate change adaptation: Barriers to adoption and drivers for uptake by spatial planners." Landscape and Urban Planning 138:155-63. doi: 10.1016/j.landurbplan.2015.02.010.

McCann, Eugene. 2013. "Policy Boosterism, Policy Mobilities, and the Extrospective City." Urban Geography 34 (1):5-29. doi: 10.1080/02723638.2013.778627.

McLean, Bronwyn L., and Thomas Borén. 2015. "Barriers to implementing sustainability locally: a case study of policy immobilities." Local Environment 20 (12):1489-506. doi: 10.1080/13549839.2014.909798.

Mell, lan C. 2017. "Green infrastructure: reflections on past, present and future praxis." Landscape Research 42 (2):135-45. doi: 10.1080/01426397.2016.1250875.

Millington, Nate, and Mary Lawhon. 2018. "Geographies of waste: Conceptual vectors from the Global South." Progress in Human Geography:0309132518799911. doi: 10.1177/0309132518799911.

Mudu, Pierpaolo, and Alessia Marini. 2018. "Radical Urban Horticulture for Food Autonomy: Beyond the Community Gardens Experience." Antipode 50 (2):549-73.

OECD. 2019. "Urban Green Growth in Dynamic Asia." Organisation for Economic Co-operation and Development, Accessed 16 January. https://www.oecd.org/environment/urban-greengrowth-in-dynamic-asia-9789264266360-en.htm.

Ostrom, Elinor. 1990. Governing the Commons. New York: Cambridge University Press.

Powell, Ryan, and John Lever. 2015. "Europe's perennial 'outsiders': A processual approach to Roma stigmatization and ghettoization." Current Sociology 65 (5):680-99. doi: 10.1177/0011392115594213.

Ramakrishnan, Kavita. 2014. "Disrupted Futures: Unpacking Metaphors of Marginalization in Eviction and Resettlement Narratives." Antipode 46 (3):754-72. doi: 10.1111/anti.12067.

Ramyar, R., and E. Zarghami. 2017. "Green Infrastructure Contribution for Climate Change Adaptation in Urban Landscape Context " Applied Ecology \& Environmental Research 15 (3):1193-209. doi: 10.15666/aeer/1503_11931209.

Sandhu, Sonia Chand, Ramola Naik Singru, John Bachmann, Vaideeswaran Sankaran, and Pierre Arnoux. 2019. "GrEEEn Solutions for Livable Cities." Asian Development Bank (ADB), Accessed 20 June. https://www.adb.org/sites/default/files/publication/181442/greeensolutions-livable-cities.pdf.

Sheller, Mimi. 2016. "Uneven Mobility Futures: A Foucauldian Approach." Mobilities 11 (1):15-31. doi: 10.1080/17450101.2015.1097038.

-- - 2018. Mobility Justice: The Politics of Movement in an Age of Extremes. Brooklyn, NY: Verso.

Shiree-DSK. 2019. "Moving Backwards: Korail Slum Eviction." Shiree-DSK, Accessed 4 April. https://assets.publishing.service.gov.uk/media/57a08a9aed915d622c0007f7/KorailEviction-Report.pdf.

Sovacool, Benjamin K., Anthony L. D'Agostino, Harsha Meenawat, and Amireeta Rawlani. 2012. "Expert Views of Climate Change Adaptation in Least Developed Asia." Journal of Environmental Management 97:78-88. doi: 10.1016/j.jenvman.2011.11.005. 
Stabrowski, Filip. 2014. "New-Build Gentrification and the Everyday Displacement of Polish Immigrant Tenants in Greenpoint, Brooklyn." Antipode 46 (3):794-815. doi: 10.1111/anti.12074.

Suykens, B. 2015. "The land that disappeared: Forceful occupation, disputes and the negotiation of landlord power in a bangladeshi bastee." Development and Change 46 (3):486-507. doi: 10.1111/dech.12165.

Swapan, Mohammad Shahidul Hasan, and Shahed Khan. 2018. "From authoritarian transplantation to prescriptive imposition of good governance: tracing the diffusion of western planning concepts in Bangladesh." International Planning Studies 23 (4):340-54. doi: 10.1080/13563475.2018.1489786.

Tappert, Simone, Tanja Kloti, and Matthias Drilling. 2018. "Contested urban green spaces in the compact city: The (re-)negotiation of urban gardening in Swiss cities." Landscape and Urban Planning 170:69-78. doi: 10.1016/j.landurbplan.2017.08.016.

Temenos, Cristina, and Eugene McCann. 2013. "Geographies of Policy Mobilities." Geography Compass 7 (5):344-57. doi: 10.1111/gec3.12063.

Thorne, C. R., E. C. Lawson, C. Ozawa, S. L. Hamlin, and L. A. Smith. 2018. "Overcoming uncertainty and barriers to adoption of Blue-Green Infrastructure for urban flood risk management." Journal of Flood Risk Management 11:S960.

Threlfall, Caragh G., Luis Mata, Jessica A. Mackie, Amy K. Hahs, Nigel E. Stork, Nicholas S. G. Williams, and Stephen J. Livesley. 2017. "Increasing biodiversity in urban green spaces through simple vegetation interventions." Journal of Applied Ecology 54 (6):1874-83. doi: 10.1111/13652664.12876.

UNDP. 2019. "Housing Solutions for the Urban Poor in Bangladesh." UNDP Bangladesh, Accessed 10 April.

https://www.bd.undp.org/content/bangladesh/en/home/presscenter/pressreleases/2019/0 4/07/housing-solutions-for-the-urban-poor-in-bangladesh.html.

United Nations. 2019. "The Sustainable Development Goals Report 2016." United Nations, Accessed 15 March.

http://ggim.un.org/documents/The\%20Sustainable\%20Development\%20Goals\%20Report\% 202016.pdf.

Vollmer, Bastian A. 2017. "Security or insecurity? Representations of the UK border in public and policy discourses." Mobilities 12 (3):295-310. doi: 10.1080/17450101.2017.1278970. 